University of Nebraska - Lincoln

DigitalCommons@University of Nebraska - Lincoln

Papers in the Earth and Atmospheric Sciences

Earth and Atmospheric Sciences, Department

2-8-2001

\title{
Tropical Climate Changes at Millennial and Orbital Timescales on the Bolivian Altiplano
}

\author{
Paul A. Baker \\ Duke University, pbaker@duke.edu \\ Catherine A. Rigsby \\ East Carolina University \\ Geoffrey O. Seltzer \\ Syracuse University \\ Sherilyn C. Fritz \\ University of Nebraska-Lincoln, sfritz2@unl.edu \\ Tim K. Lowenstein \\ sUNY Binghamton \\ See next page for additional authors
}

Follow this and additional works at: https://digitalcommons.unl.edu/geosciencefacpub

Part of the Earth Sciences Commons

Baker, Paul A.; Rigsby, Catherine A.; Seltzer, Geoffrey O.; Fritz, Sherilyn C.; Lowenstein, Tim K.; Bacher, Niklas P.; and Veliz, Carlos, "Tropical Climate Changes at Millennial and Orbital Timescales on the Bolivian Altiplano" (2001). Papers in the Earth and Atmospheric Sciences. 47.

https://digitalcommons.unl.edu/geosciencefacpub/47

This Article is brought to you for free and open access by the Earth and Atmospheric Sciences, Department of at DigitalCommons@University of Nebraska - Lincoln. It has been accepted for inclusion in Papers in the Earth and Atmospheric Sciences by an authorized administrator of DigitalCommons@University of Nebraska - Lincoln. 


\section{Authors}

Paul A. Baker, Catherine A. Rigsby, Geoffrey O. Seltzer, Sherilyn C. Fritz, Tim K. Lowenstein, Niklas P. Bacher, and Carlos Veliz 
Published in Nature 409 (February 8, 2001), pp. 698-701; doi 10.1038/35055524 Copyright (C 2001 Macmillan Magazines Ltd. http://www.nature.com Used by permission.

Submitted May 3, 2000; accepted November 22, 2000

\section{Tropical Climate Changes at Millennial and Orbital Timescales on the Bolivian Altiplano}

\author{
Paul A. Baker ${ }^{1}$, Catherine A. Rigsby ${ }^{2}$, Geoffrey O. \\ Seltzer ${ }^{3}$, Sherilyn C. Fritz ${ }^{4}$, Tim K. Lowenstein ${ }^{5}$, \\ Niklas P. Bacher ${ }^{1}$, and Carlos Veliz ${ }^{3}$
}

\footnotetext{
${ }^{1}$ Duke University, Division of Earth and Ocean Sciences, Durham, North Carolina 27708-0227, USA

${ }^{2}$ East Carolina University, Department of Geology, Greenville, North Carolina 27858, USA

${ }^{3}$ Syracuse University, Department of Earth Sciences, Syracuse, New York 13244, USA

${ }^{4}$ University of Nebraska-Lincoln, Department of Geosciences and School of Biological Sciences, Lincoln, Nebraska 68588-0340, USA

${ }^{5}$ SUNY Binghamton, Department of Geological Sciences, Binghamton, New York 13902, USA

Corresponding author: Paul A. Baker, email pbaker@geo.duke.edu
}

\begin{abstract}
Tropical South America is one of the three main centers of the global, zonal overturning circulation of the equatorial atmosphere (generally termed the "Walker" circulation ${ }^{1}$ ). Although this area plays a key role in global climate cycles, little is known about South American climate history. Here we describe sediment cores and down-hole logging results of deep drilling in the Salar de Uyuni, on the Bolivian Altiplano, located in the tropical Andes. We demonstrate that during the past 50,000 years the Altiplano underwent important changes in effective moisture at both orbital (20,000-year) and millennial timescales. Long-duration wet periods, such as the Last Glacial Maximummarked in the drill core by continuous deposition of lacustrine sediments-appear to have occurred in phase with summer insolation maxima produced by the Earth's precessional cycle. Short-duration, millennial events correlate well with North Atlantic cold events, including Heinrich events 1 and 2, as well as the Younger Dryas episode. At both millennial and orbital timescales, cold sea surface temperatures in the high-latitude North Atlantic were coeval with wet conditions in tropical South America, suggesting a common forcing.
\end{abstract}

The Salar de Uyuni (Figure 1), located on the Bolivian Altiplano at an elevation of 3,653 m above sea level, is the world's largest salt flat. The salar was formerly occupied by a series of large lakes. ${ }^{2}$ The youngest was a shallow palaeolake, "Coipasa," radiocarbon-dated ${ }^{3}$ between 11,500 and 13,400 calendar years before present (cal. yr bp). The youngest deep palaeolake, "Tauca," was previously dated using carbonate fossils from outcropping sediments and carbonate bioherms (reefs) that mark past highstands. Published radiocarbon dates 3,4 indicate that palaeolake Tauca existed from about 13,000 to 18,000 cal. yr bp (we judge the published U-Th dates of the same deposits to be less reliable than the published radiocarbon dates because of large corrections necessitated by the high values of excess thorium in the samples). Palaeolake Tauca attained a maximum depth of $140 \mathrm{~m}$ (ref. 5). The existence of an older deep palaeolake, "Minchin," was postulated on the basis of two published radiocarbon dates (about 30,000 and 32,000 cal. yr bp; ref. 2) of shells from outcropping sediments. The evidence for the existence of these, and even older, palaeolakes on the Altiplano has been well summarized. ${ }^{6}$
In the summer of 1999 we drilled and continuously cored the Salar de Uyuni to a depth of $220.6 \mathrm{~m}$ below the surface. The drill hole was located in the central portion of the salar $\left(20^{\circ} 14.97^{\prime} \mathrm{S}, 67^{\circ} 30.03^{\prime} \mathrm{W}\right)$. The cased hole was subsequently logged at $10-\mathrm{cm}$ intervals, using a tool (manufactured by Delta Epsilon, Inc.) that measures natural $\gamma$-rays, to a depth of $188.7 \mathrm{~m}$ subsurface. Here we present and discuss the stratigraphy and logging results of the radiocarbon-dated portion of the core, the upper $35 \mathrm{~m}$.

The most important result of our study is the identification and dating (Table 1) of wet and dry events on the Altiplano (Figure 2a) for the past 50,000 cal. yr. The wet events are signalled in the drill core by the muds containing abundant diatoms that indicate deposition in perennial lakes varying from shallow to deep and low to high salinity. The dry events are marked by salt deposits that consist mainly of halite $(\mathrm{NaCl})$ and gypsum $\left(\mathrm{CaSO}_{4}\right)$. Salt textures indicate deposition in a variety of palaeoenvironments, ranging from perennial hypersaline lakes to annually desiccated saline pans similar to the modern Salar de Uyuni. Because the lacustrine muds have much higher values of natural $\gamma$-radiation than do the salt deposits, the continuous downhole record of natural $\gamma$-radiation (Figure 2a) is a sensitive measure of changing effective moisture through time.

The shallowest peak of $\gamma$-radiation, indicating the former existence of a lake, is between 6.3 and $7.0 \mathrm{~m}$ subsurface. Incomplete recovery of sediment precluded direct dating of this

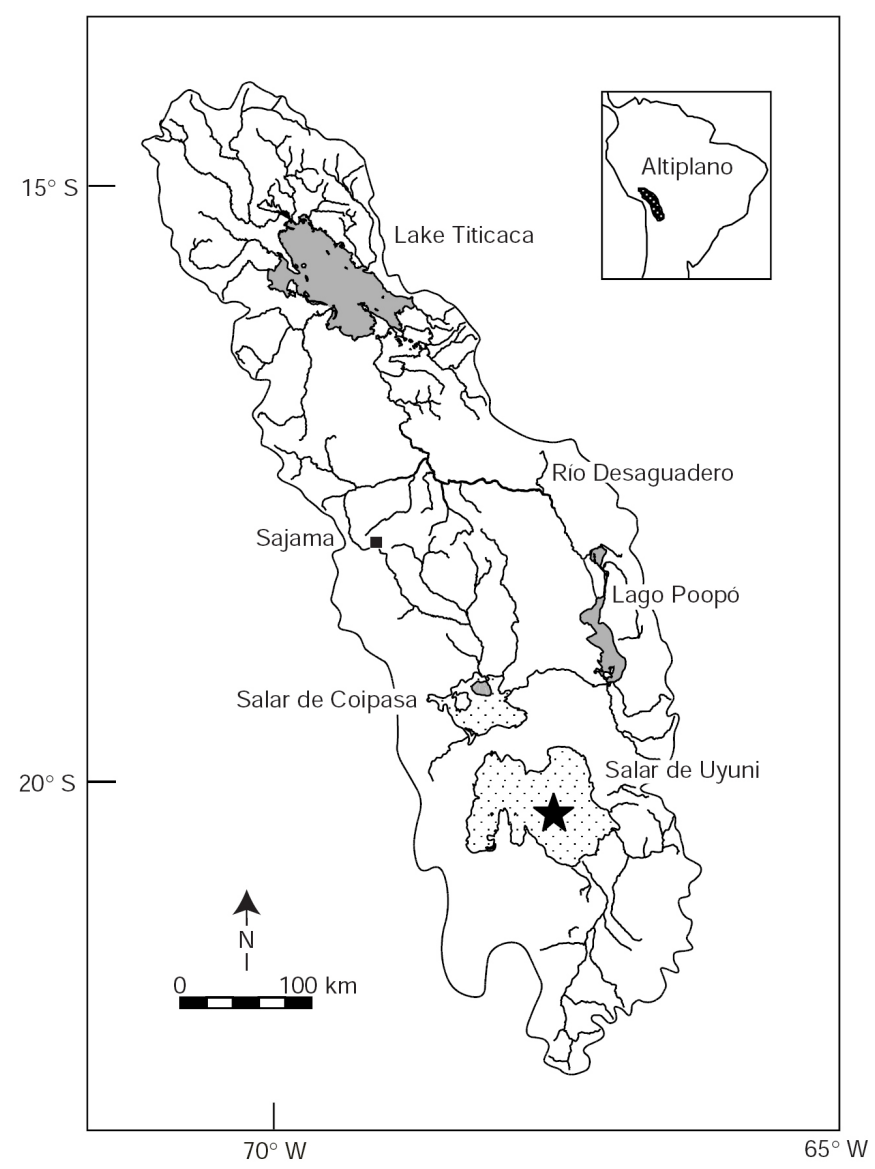

Figure 1. Map showing the location of the Altiplano and the Salar de Uyuni. During wet phases, Lake Titicaca overflows, and drains via the Rio Desaguadero into Lago Poopó. In extremely wet periods, Lago Poopó can discharge into Salar de Coipasa and Salar de Uyuni. Star-location of the drill core; filled square-location of Volcan Sajama. 
interval, the probable equivalent of palaeolake "Coipasa." Our (extrapolated) age for this palaeolake is about 12,500 cal. yr bp, contemporaneous with the Younger Dryas cold event of high northern latitudes. ${ }^{7}$ A $\gamma$-radiation minimum between 7.0 and $8.0 \mathrm{~m}$ records a dry period with salt deposition from about 12,500 to 14,900 cal. yr bp, contemporaneous with the Bølling-Allerød interstadial. Lacustrine muds were recovered between 8.0 and $14.0 \mathrm{~m}$ subsurface. We attribute these sediments to palaeolake Tauca, but our dates for this period extend to much older intervals than those previously published, ranging from 14,900 to $26,100 \mathrm{cal}$. yr bp. The two $\gamma$-radiation maxima within this interval, dated at 14,900-16,600 and 24,300-26,100 cal. yr bp, coincide respectively with Heinrich events 1 and 2a. ${ }^{7}$ Underlying the Tauca sediments, between 14.0 and $20.4 \mathrm{~m}$ subsurface are two minor lacustrine muds marked by smaller $\gamma$-radiation maxima, dated at 28,200 30,800 and $31,800-33,400$ cal. yr bp, that coincide with two sea surface temperature (SST) maxima observed in the subtropical North Atlantic. ${ }^{7}$ These muds are interbedded with halite that formed during dry periods. The second youngest major lacustrine interval extends from $20.4 \mathrm{~m}$ to $33.3 \mathrm{~m}$ subsurface. A sample from near the top of this interval yielded a reliable age of about 42,000 cal. yr bp, yielding an interpolated age for the top of the interval of 38,100 cal. yr bp. Deeper samples were beyond the range of radiocarbon dating. We attribute this interval to palaeolake Minchin; thus, palaeolake Minchin is much older than previously believed. Underlying the Minchin bed is a 7-m-thick salt bed that is, in turn, underlain by a third major, as yet undated, lacustrine interval.

A recent global climate modelling experiment, ${ }^{8}$ utilizing new sea surface palaeotemperature estimates, ${ }^{9}$ yielded a mean annual temperature lowering of $5^{\circ} \mathrm{C}$ relative to modern for the Last Glacial Maximum (LGM) in this part of the tropical Andes. Studies of the depression of snowline elevation have concluded variously that the mean annual temperature change for the LGM in this part of the Andes ranged anywhere from $2-3{ }^{\circ} \mathrm{C}$ (refs 10,11$)$ to $5-9{ }^{\circ} \mathrm{C}$ (ref. 12). Model calculations of the amount of precipitation needed to maintain large palaeolakes on the Altiplano against desiccation by evaporation ${ }^{13}$ necessitate about $30 \%$ higher-than-modern precipitation, even with temperatures $5{ }^{\circ} \mathrm{C}$ lower than modern. We conclude that the lacustrine episodes observed in our drill core were not produced solely by lower temperatures; their formation also required significantly higher amounts of precipitation on the Altiplano than today.

The austral summer is the season of maximum precipitation in the southern tropics of South America (including the Altiplano)- on the Altiplano an average of $75 \%$ of the total annual precipitation falls in the months of DecemberMarch. During the austral summer, atmospheric water vapor, ultimately derived from the tropical Atlantic Ocean, is advected across the Amazon basin to the centre of deep convection developed in the Gran Chaco region to the east of the Altiplano. This climatological system has been referred to as the South American summer monsoon (SASM). ${ }^{14}$ We propose that in the past the first-order control on the variability of precipitation on the Altiplano was variability of the SASM produced by changes in summertime insolation. Indeed, the main wet and dry phases on the Altiplano occurred, respectively, in phase with summertime (January) insolation maxima and minima (Figure 2a), calculated for $15^{\circ} \mathrm{S}$ latitude from Earth's known orbital variations. ${ }^{15}$ For example, the intervals 14,900-26,100 cal. yr bp (including the LGM) and 38,100 to
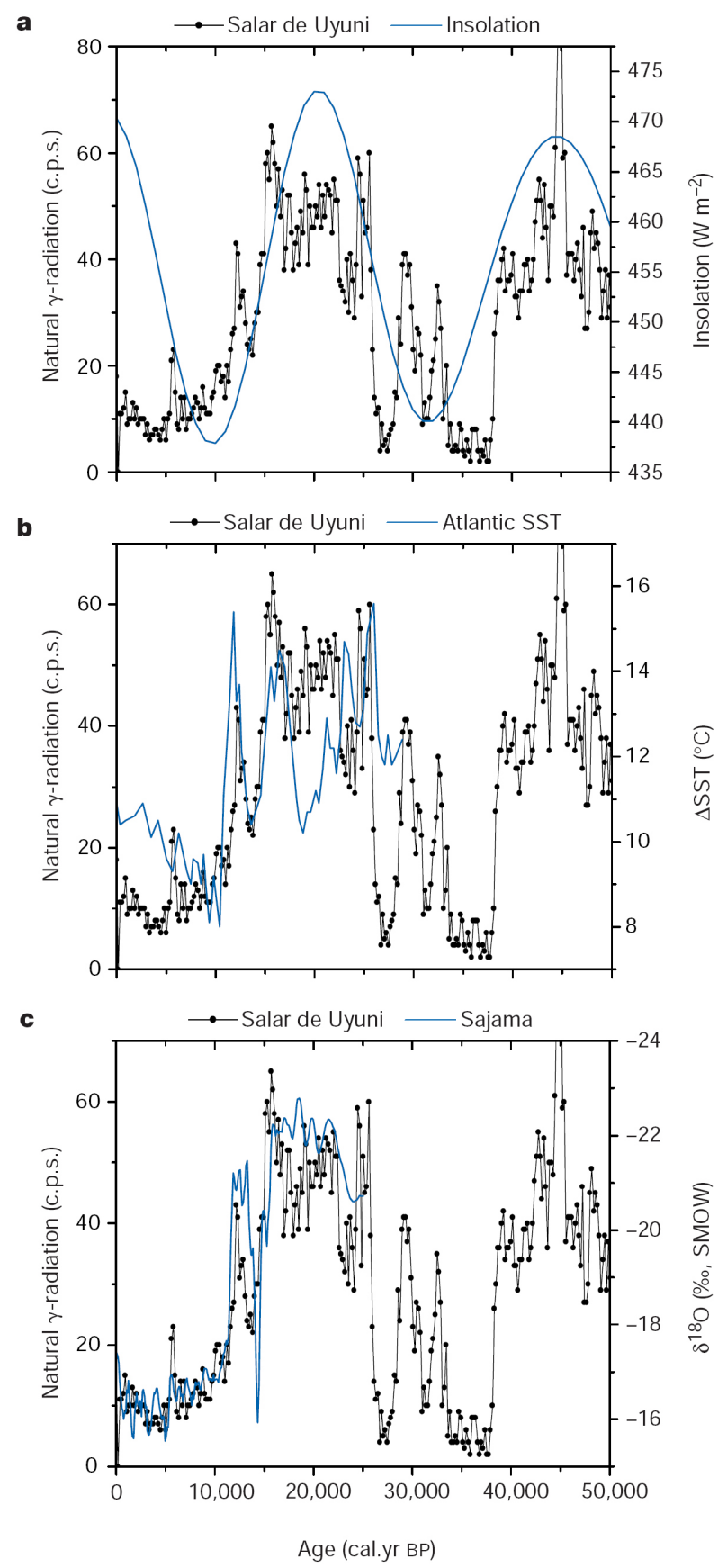

Figure 2. Logging data from the Salar de Uyuni compared to other reconstructed palaeoclimatic time series. The figure compares natural $\mathrm{y}$-radiation in the salar drill hole, our proxy for effective moisture, with calculated summer insolation, reconstructed records of sea surface temperature (SST) gradients in the equatorial Atlantic sector, and the record of stable oxygen isotopes in the Sajama ice cap. (a) Natural y-radiation (black line and dots) versus calendar age determined by radiocarbon measurement (Table 1). Natural $\mathrm{Y}$-radiation is mostly produced by the decay of radioactive $\mathrm{K}, \mathrm{U}$, and Th, elements that are more concentrated in the lacustrine muds than in the salt deposits. The high values of natural $\mathrm{y}$-radiation centred at 45,000 cal. yr bp are due to volcanic ash. Blue line, palaeoinsolation at $15^{\circ} \mathrm{S}$ latitude calculated for the month of January. ${ }^{15}$ (b) Natural $\gamma$ radiation (black line) versus calendar age. Blue line, $\triangle \mathrm{SST}$, the difference in reconstructed SST between the western tropical North Atlantic ${ }^{18}$ and the eastern subtropical North Atlantic. ${ }^{7}$ Values of reconstructed SST (using the calibration of Muller et $\mathrm{al}^{23}$ ) and age were interpolated from both studies, then differenced. (c) Natural y-radiation (black line) versus calendar age. Blue line, the smoothed record (3-point moving average of the 100-year average record; L. Thompson, personal communication) of $\delta^{18} \mathrm{O}$ of ice in the Sajama ice cap. ${ }^{22}$ 
of maximum wetness and maximum insolation on the Altiplano. An apparent exception to this hypothesized control is the lack of a modern lake in the Salar de Uyuni in the present time of high summer insolation. However, the late Holocene is a relatively wet period on the Altiplano-Lake Titicaca has been at or near its overflow level since about 3,500 cal. yr bp (ref. 16), and small lakes (such as modern Lago Poopó) have existed on the central Altiplano during much of this period. ${ }^{17}$ Also, the late Holocene is warmer than the LGM, contributing to a higher rate of evaporation. It is clear that the SASM did not decrease in intensity during the LGM, despite colder tropical SST. Instead, increased land-sea temperature gradients and increased interhemispheric meridional SST gradients, ${ }^{9}$ combined with peak wet-season insolation, resulted in an enhanced SASM and enhanced precipitation in much of tropical South America.

Superimposed upon the first-order orbital control of moisture, we observed many high-amplitude, but shorter (millennial) duration peaks of $\gamma$-radiation indicative of the former presence of lakes on the Altiplano, even during time periods calculated to have relatively low summertime insolation. Allowing for reasonable dating errors, each peak corresponds with an SST minimum reconstructed for the subtropical eastern North Atlantic $\left(38^{\circ} \mathrm{N}, 10^{\circ} \mathrm{W}\right)$ SST. ${ }^{7}$ When eastern North Atlantic SST is subtracted from western North Atlantic $\left(12^{\circ} \mathrm{N}, 61^{\circ} \mathrm{W}\right) \mathrm{SST}^{18}$ the resulting $\triangle \mathrm{SST}$ (Figure $\left.2 \mathrm{~b}\right)$ is a useful

Table 1 Radiocarbon dates of sediments from the Salar de Uyuni core

\begin{tabular}{lcccc}
\hline Sample & AMS no. & $\begin{array}{c}\delta^{13} \mathrm{C} \\
\% \text { PDB })\end{array}$ & $\begin{array}{c}\text { Radiocarbon age } \\
\text { (yr BP) }\end{array}$ & $\begin{array}{c}\text { Calibrated age } \\
\text { (yr BP) }\end{array}$ \\
\hline SU 6.91 & OS-26880 & -16.0 & $10,980 \pm 55$ & 13,074 \\
SU 8.47 & OS-21541 & -13.9 & $13,800 \pm 100$ & 16,560 \\
SU 9.78 & OS-26878 & -13.9 & $13,840 \pm 65$ & 16,606 \\
SU10.20 & OS-21542 & -13.6 & $18,920 \pm 250$ & 22,450 \\
SU 13.35 & OS-21543 & -13.4 & $19,250 \pm 190$ & 22,830 \\
SU 15.14 & OS-21544 & -13.5 & $23,600 \pm 190$ & 27,750 \\
SU 15.72 & OS-21545 & -13.4 & $24,100 \pm 200$ & 28,320 \\
SU 16.22 & OS-21546 & -13.3 & $24,000 \pm 800$ & 28,210 \\
SU 17.09 & OS-21547 & -13.4 & $23,900 \pm 190$ & 28,100 \\
SU 17.70 & OS-21548 & -15.9 & $32,600 \pm 410$ & 37,830 \\
SU 18.37 & OS-21549 & -15.5 & $31,500 \pm 480$ & 36,630 \\
SU 22.78 & OS-21550 & -17.6 & $36,300 \pm 590$ & 41,840 \\
SU 24.04 & OS-21751 & -15.4 & $>45,000$ & $>51,000$ \\
SU 27.25 & OS-21752 & -17.9 & $>45,000$ & $>51,000$ \\
SU 28.15 & OS-21753 & -17.7 & $>45,000$ & $>51,000$ \\
SU 28.40 & OS-21754 & -15.9 & $>45,000$ & $>51,000$ \\
SU 30.74 & OS-21755 & -15.9 & $>45,000$ & $>51,000$ \\
\hline
\end{tabular}

Radiocarbon dates were determined by accelerator mass spectrometry (AMS) on the total organic carbon fraction of the lacustrine muds or salts. These dates were calibrated using Calib 4.1.224,25 for samples less than $24,000 \mathrm{cal}$. yr BP, and using a quadratic equation ${ }^{26}$ for older samples. Our age \pm depth model is a linear, least-squares fit assuming a surface age of zero. Ages are corrected for stable isotopic fractionation, but not for reservoir effects. Large reservoir effects are present in some groundwater-dominated lakes of the Chilean Altiplano ${ }^{27}$ and have been suggested for palaeolake "Coipasa."4 We doubt, however, that significant reservoir effects were present in the larger palaeolakes. For example, the large, deep basin of modern Lake Titicaca has no appreciable reservoir effect, ${ }^{28}$ although a 250 year reservoir correction is needed for the shallow, semi-isolated basin of the modern lake. ${ }^{16}$ The major lake phases of the Salar de Uyuni coincided with higher-than-modern levels of Lake Titicaca, hence greater-than-modern throughflow rates of water in that lake. ${ }^{28}$ At those times, Lake Titicaca was deep, fresh, and overflowing to the south, contributing about one-third of the total input to palaeolakes "Minchin" and "Tauca." ${ }^{29}$ The large surface area-to-volume ratio of these two palaeolakes would have promoted rapid exchange of dissolved $\mathrm{CO}_{2}$ with atmospheric $\mathrm{CO}_{2}$. Finally, there is little carbonate rock in the watershed of the Salar de Uyuni. Under these conditions it is difficult to envision a significant flux of non-atmospheric carbon into the palaeolakes, and we conclude that any reservoir effect is small. measure of palaeoatmospheric dynamics (we note that there are also very similar, but not as well dated, SST reconstructions ${ }^{19}$ in the eastern tropical Atlantic at $21^{\circ} \mathrm{N}, 19^{\circ} \mathrm{W}$ and $19^{\circ} \mathrm{N}, 20^{\circ} \mathrm{W}$ ). In the modern ocean, high values of this index would be expected to correlate with enhanced northeast trade winds ${ }^{20}$ and, as observed, increased advection of moisture to the Amazon and the Altiplano. ${ }^{21}$ The Salar de Uyuni record provides the best demonstration to date that millennial-scale Heinrich events occurred in southern tropical South America, where they are manifested as wet, not cold, periods.

The oxygen isotope record of the nearby (Figure 1) ice cap of Volcan Sajama ${ }^{22}$ has a similar structure to the Salar $\gamma$-radiation record (Figure 2c), bolstering the argument that $\delta^{18} \mathrm{O}_{\text {ice }}$ is inversely correlated with precipitation amount (or runoff fraction). ${ }^{10}$ The base of the ice core coincides in age with the basal sediments of palaeolake Tauca $(26,100 \mathrm{cal}$. yr bp), suggesting that the preceding dry phase had resulted in the complete loss of ice on Sajama (and perhaps elsewhere in the western Andean Cordillera).

We have reconstructed the timing and direction of large changes of precipitation on the Altiplano over the past $50,000 \mathrm{yr}$. The general agreement between the timing of the longest wet phases and periods of above-average summer insolation supports a first-order orbital control of the intensity of the SASM. Furthermore, all wet phases at both orbital and millennial scale coincide with anomalously large zonal SST gradients (warm west and cold east) across the equatorial Atlantic Ocean, the ultimate moisture source for the Altiplano.

\section{Acknowledgments}

We thank O. Ballivian and J. Bohorquez for their assistance in the planning and field work for this project. This work was supported by the US National Science Foundation.

\section{References}

1. Hastenrath, S. Climate Dynamics of the Tropics (Kluwer Academic, Dordrecht, 1994).

2. Servant, M. \& Fontes, J.-C. Les lacs quaternaires des hauts plateaux des Andes boliviennes: premières interprétations paléoclimatiques. Cah. ORSTOM Ser. Geol. 10, 9-24 (1978).

3. Servant, M. et al. La dernière transition glaciaire/interglaciaire des Andes tropicales sud (Bolivie) d'apres l'étude des variations des niveaux lacustres et des fluctuations glaciaires. C.R. Acad. Sci. Paris 320, 729-736 (1995).

4. Sylvestre, F. et al. Lake-level chronology on the southern Bolivian Altiplano $\left(18^{\circ}-23^{\circ} \mathrm{S}\right)$ during late-glacial time and the early Holocene. Quat. Res. 51, 54-66 (1999).

5. Bills, B. G. et al. Hydro-isostatic deflection and tectonic tilting in the central Andes: Initial results of a GPS survey of Lake Minchin shorelines. Geophys. Res. Lett. 21, 293-296 (1994).

6. Clapperton, C. M. Quaternary Geology and Geomorphology of South America (Elsevier, Amsterdam, 1993).

7. Bard, E. , Rostek, F. , Turon, J.-L. \& Gendreau, S. Hydrological impact of Heinrich events in the subtropical Northeast Atlantic. Science 289, 1321-1324 (2000).

8. Hostetler, S. W. \& Mix, A. Reassessment of ice-age cooling of the tropical ocean and atmosphere. Nature 399, 673-676 (1999).

9. Mix, A. C. , Morey, A. E. , Pisias, N. G. \& Hostetler, S. W. Foraminiferal faunal estimates of paleotemperature: circumventing the noanalog problem yields cool ice age tropics. Paleoceanography 14, 350-359 (1999). 
10. Pierrehumbert, R. T. Huascaran $\delta^{18} \mathrm{O}$ as an indicator of tropical climate during the Last Glacial Maximum. Geophys. Res. Lett. 26, 1345-1348 (1999).

11. Betts, A. K. \& Ridgway, W. Tropical boundary-layer equilibrium in the last ice-age. J. Geophys. Res. 97, 2529-2534 (1992).

12. Klein, A. G. , Seltzer, G. O. \& Isacks, B. C. Modern and last local glacial maximum snowlines in the central Andes of Peru, Bolivia, and northern Chile. Quat. Sci. Rev. 18, 63-84 (1999).

13. Blodgett, T. A. , Lenters, J. D. \& Isaacks, B. L. Constraints on the origin of paleolake expansions in the central Andes. Earth Interactions [online] http://earthinteractions.org (1997).

14. Zhou, J. \& Lau, K.-M. Does a monsoon climate exist over South America? J. Clim. 11, 1020-1040 (1998).

15. Berger, A. \& Loutre, P. J. Insolation values for the climate of the last 10 million years. Quat. Sci. Rev. 10, 297-317 (1991).

16. Abbott, M. B. , Binford, M. B. , Brenner, M. W. \& Kelts, K. R. A 3500 ${ }^{14} \mathrm{C}$ yr high resolution record of lake level changes in Lake Titicaca, South America. Quat. Res. 47, 169-180 (1997).

17. Baucom, P. C. \& Rigsby, C. A. Climate and lake-level history of the northern Altiplano, Bolivia, as recorded in Holocene sediments of the Rio Desaguadero. J. Sedim. Res. 69, 597-611 (1999).

18. Rühlemann, C., Mulltza, S., Müller, P. , Wefer, G. \& Zahn, R. Warming of the tropical Atlantic Ocean and slowness of thermohaline circulation during the last deglaciation. Nature 402, 511-514 (1999).

19. Zhao, M. , Beveridge, N. A. S., Shackleton, N. J., Sarnthein, M. \& Eglinton, G. Molecular stratigraphy of cores off northwest Africa: Sea surface temperature history over the last $80 \mathrm{ka}$. Paleoceanography 10, 661-675 (1995).
20. Servain, J., Wainer, I. , Ayina, H. \& Roquet, H. The relationship between the simulated climate variability modes of the tropical Atlantic. Int. J. Climatol. 20, 939-953 (2000).

21. Nobre, P. \& Shukla, J. Variations of sea surface temperature, wind stress, and rainfall over the tropical Atlantic and South America. J. Clim. 9, 2464-2479 (1996).

22. Thompson, L. G. et al. A 25,000 -year tropical climate history from Bolivian ice cores. Science 282, 1858-1864 (1998).

23. Müller, P. J. , Kirst, G. , Ruhland, G. , von Storch, L. \& Rosell-Melé, A. Calibration of the alkenone paleotemperature index $\mathrm{UK}^{\prime}{ }_{37}$ based on core-tops from the eastern South Atlantic and the global ocean $\left(60^{\circ} \mathrm{N}-60^{\circ} \mathrm{S}\right)$. Geochim. Cosmochim. Acta 62, 1757-1772 (1998).

24. Stuiver, M. \& Reimer, P. J. Extended ${ }^{14} \mathrm{C}$ data base and revised CALIB $3.0{ }^{14} \mathrm{C}$ age calibration program. Radiocarbon $35,215-230$ (1993).

25. Stuiver, M. et al. INTCAL98 radiocarbon age calibration, 24,000-0 cal BP. Radiocarbon 40, 1041-1083 (1998).

26. Bard, E. Geochemical and geophysical implications of the radiocarbon calibration. Geochim. Cosmochim. Acta 62, 2025-2038 (1998).

27. Geyh, M. A. , Schotterer, U. \& Grosjean, M. Temporal changes of the ${ }^{14} \mathrm{C}$ reservoir effect in lakes. Radiocarbon 40, 921-931 (1998).

28. Baker, P. et al. The history of South American tropical climate for the past 25,000 years from the sedimentary record of Lake Titicaca (Bolivia/Peru). Science (in the press).

29. Grove, M. J. Paleoclimatology and Sedimentology of the Late Pleistocene and Holocene from Lake Titicaca, Bolivia-Peru. Thesis, Duke Univ. (2000). 